\title{
DESIGNING LEEF APPLICATION (LEARNING ENGLISH EASY AND FUN) AS LEARNING MEDIA AT THE SEVENTH GRADE STUDENTS OF JUNIOR HIGH SCHOOL
}

\author{
Iin Baroroh Ma'arif ${ }^{1}$, Yuyun Bahtiar ${ }^{2}$, \& Muthoharoh ${ }^{3 *}$ \\ 1,2,3Universitas KH. A. Wahab Hasbullah \\ *iinmaarif@unwaha.ac.id
}

\begin{abstract}
This research aims at designing a learning media which named LEEF (Learning English Easy and Fun) as English learning media for seventh grade students of Junior High School. This learning media consists of some materials and exercises which is appropriate and feasible to be studied for students. All materials in this media are based on junior high school syllabus of K13 curriculum. The research method used in this research is Research and Development. This development used ADDIE model which have several steps, those are; 1) Analysis, 2) Design, 3) Development, 4) Implementation, and 5) Evaluation. The result of this research shows that from the media validation result got 4.00 score it was in "fair and worth to use" category, and the material validation got 3.86 score. The students' responses of try out result score 4.26 were in "fair and worth to use" category. By having those result, this LEEF (Learning English Easy and Fun) is feasible to be used as a learning media for seventh grade students of junior high school. Furthermore, this research can be used as reference to other researchers in developing English learning media in different level of students.
\end{abstract}

Keywords: English for Junior High School, Learning Media, Learning English Easy and Fun

\section{INTRODUCTION}

Education has an essential role in the development of a country. Because of that, the government improves the quality of education in Indonesia. Those efforts were such as reform the curriculum, improve teachers' skills, and provide the facilities and media that support the teaching-learning process. The government expects that those efforts can make the teaching-learning process run well and increase students' achievement.

English has an essential role as a means of international communication in the global era. As one of the international languages, English is commonly used in public service, mass media, literature, text books, etc. People learn English for several purposes. For example, professional workers know English to make communication with the clients easier, and university students learn English to explore the English literature books to improve their knowledge. Furthermore, the school level, at senior high school, junior high school, and elementary school, the students learn English as a compulsory subject/material. (Baroroh, 2018) 
Teaching is the process of guiding students to achieve their purpose. Teaching, also known as "instruction", means the act of helping others understand. Teaching is an interactive activity involving classroom lectures between teachers and students. English is hard to learn because it has different grammatical structures from Bahasa Indonesia or students' mother tongue. Therefore, teachers should make English learning easy and exciting. In this case, the teachers can use Information and Communication Technology (ICT), such as interactive learning media, for teaching and learning activities.

Teaching all subjects needs learning media to make the teaching-learning process accessible and exciting, including teaching English. English is a foreign language that Indonesian students should learn. English teaching is emphasized in developing language skills, i.e., reading, listening, speaking, and writing. As a part of the schools' subjects, Indonesian students should learn English by mastering the four skills. However, it is not easy to master it since they encounter many difficulties. Those difficulties appear because of many causes. (Anwar, Sos, \& Si, 2016)

Media play an essential role in the teaching-learning process. Media are needed to reach the objectives of the teaching-learning process. Teachers should use various media or teaching aids in giving the material to the students as stated by Harmer (2001: 134) that "as a language teacher, we use a variety of teaching aids to explain language meaning and construction, engage students in a topic or as the basis of a whole activity." The definitions above conclude tools, materials, or events that establish conditions used by a teacher to facilitate the instruction to acquire knowledge, skill and attitudes and engage the learners in a topic or as the basis of a whole activity.

There are many advantages of interactive learning media in the English teachinglearning process. First, the students will be motivated to learn English because they will not be bored. Second, the students can easily comprehend and understand the materials because the English interactive learning media can provide video, animation, graphics, and audio. By using video and audio, they can listen to the dialogues from the native speakers directly. Therefore, they can improve their listening, speaking, and pronunciation. Graphics and animations can use to catch the students' attention. Third, the students can learn independently, whenever and where ever they want. The last is that the English teachers will have variation in teaching to avoid the tedious teaching-learning process.

However, two problems are face by most English teachers related to the use of interactive learning media. First, there is no advanced technology provided in the school. It does not have any computers and LCD in the class as facilities in the teaching-learning process. Therefore, teachers cannot use English interactive learning media. Second, the English teachers have difficulties finding the English interactive learning media appropriate to their needs. Even if the teachers find them, the price is too high. That is why most teachers teach English by using textbooks and LKS (Lembar Kerja Siswa). Therefore, some everyday activities are still listening to the teachers' explanation and reading the materials. These conditions bring effects to the students. For example, the students have low motivation and get bored in learning English. Besides, they have low achievement in all English skills, including listening skills. There is no positive effect on the students' listening 
skills, although they often listen to their explanations. It is because the teachers seldom use it in the teaching-learning process.

Using media in the classroom is very important because it can improve the quality of the teaching-learning process. Moreover, students can comprehend the lesson easily. Three types of media can be used in the teaching-learning process. They are (1) audio (tape, radio, compact disc, etc); (2) visual (pictures, poster OHP, etc); and (3) audiovisual (television, video, VCD, computer, etc).

According to (Abercrombie, 1949) media help teachers motivate students by bringing a slice of real-life into the classroom and presenting language in its more communicative context. Moreover, Sudjana and Rivai (2009: 2) state the rationales of the use of media in the teaching-learning process as follows: first, the teaching-learning process will be more attractive so that it can improve the students' motivation, second, the students will quickly understand the materials since the media will enable them to master the teaching objectives well, third, the teaching methods will be various so the students will not get bored during teaching-learning processes and last the students will be more active because they listen to the teacher's explanation and do other activities, such as observation, demonstration, etc.

According to Sudjana and Rivai (2009: 4), there are many things that teachers should consider in using media. First, the teachers should understand learning media, such as the advantages of teaching media and suitable media characteristics. Second, teachers should be able to develop teaching media. Third, the teachers should have knowledge and skills in seeing the effectiveness of the media.

In conclusion, the use of media in the teaching-learning process helps both the teachers and the students. The first is for the teachers. The teachers can avoid the tedious teaching-learning process because they have variation in teaching. Besides, the teachinglearning process will be more enjoyable. The second is for the students. Media can stimulate the students' motivation and interest. Therefore, they will be more active in the classroom. Moreover, students can understand the materials easily.

By concluding all explanation above, the objective of this research is to design an interactive learning media that can be used by the students in learning English. The learning media named LEEF (Learning English Easy and Fun). It is an English learning media for seventh grade students of Junior High School. The researchers uses the Hyperlink PowerPoint. The reason is because it is the most simple education media maker without coding skills. Then, the researchers converts it from hyperlink PowerPoint to android application. It serves colorful, compatible sound effects and exciting animation. Since the material is for Junior High School Grade VII, the researchers gives standard animation to keep the user's concentration. The researchers hoped students could understand well after playing the integrated quiz in each chapter. 


\section{METHODS}

\section{Research Design}

Research \& development is one research design aimed at developing and validating educational products. The process involves identifying problems that need to be solved by educational products, like textbooks, syllabus, assessment instruments, etc., studying the principles of writing instructional media, developing the media based on the principles, field testing it in the setting where it will be using eventually, and revising it to correct the deficiencies found in the filed-testing stage. In more rigorous programs of $R \& D$, this cycle is repeating until the field-test data indicate that the product meets its behaviorally defined objectives (Borg and Gall, 1989:772).

The background reason for this $\mathrm{R} \& \mathrm{D}$ is the classroom problems related to educational products. The problems might occur because, for example, the existing textbook is not appropriate anymore to the recently growing theory of language learning, it does not accommodate the latest curriculum, or the student's learning achievement is not as high as expected. This problem is observing by the classroom teacher who cares a lot about the students' learning achievement.

(Taylor, 2004) proposes six instructional design models. They are ADDIE, Dick and Carey, Hannifen and Perk, Knirk and Gustafson, Jerrold Kemp, and Gerlach and Ely. The ADDIE instructional design model is the generic process traditionally used by instructional designers and training developers. The five phases are Analysis, Design, Development, Implementation, and Evaluation. Those phases represent a dynamic, flexible guideline for building practical training and performance support tools.

Based on the explanation above, the researchers adapted the ADDIE as the instructional design model in this research. The ADDIE model is more accessible and less complicated than other instructional design models. Moreover, the ADDIE model is the basic model used as a source in developing different models of instructional design models.

\section{Research Procedure}

The researchers use the ADDIE design model (Taylor, 2004) to design English interactive learning media. The phases are describing in the following figure:

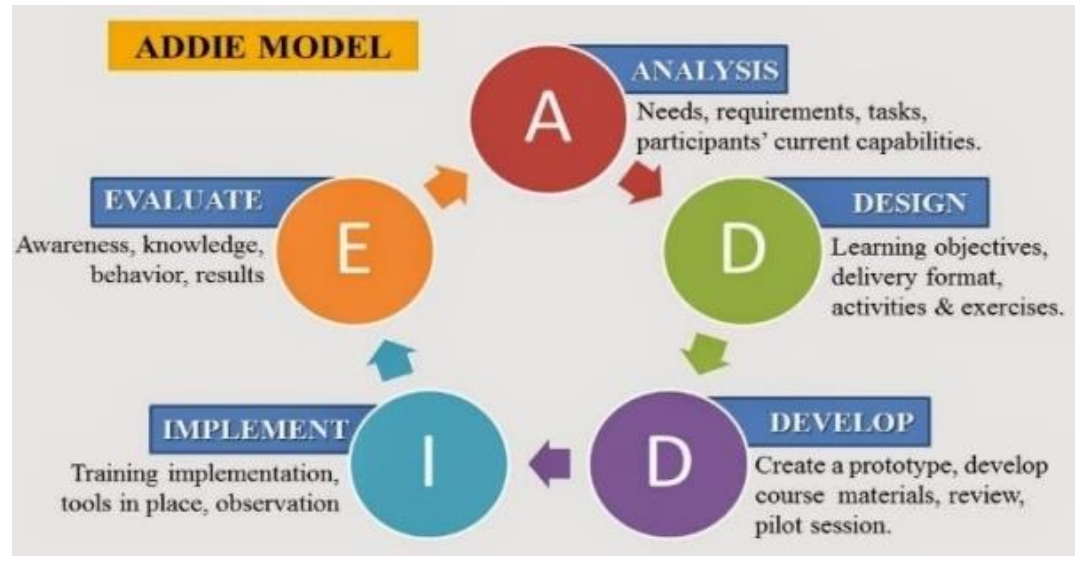

Figure 1. ADDIE model 


\section{Analysis}

In this step, the researchers conduct observation and need analysis. The researchers conduct the need analysis to find information about the students' need in learning English by using the questionnaire. The result of the need analysis is used as guidelines in designing English interactive learning media.

\section{Design}

The researchers select the topics and objectives of the materials suitable for the school-based curriculum and the materials taught by the English teacher. Then, the researchers design the course grid and materials.

The researchers develop media by using Hyperlink PowerPoint to make the interest of this media. It contains 12 materials. Each chapter will contain materials, video materials, exercises, and quiz. Materials button to give explanations about that material. Video material is a button to provide visual proof. Exercises are buttons to provide an activity that students must submit to the teacher. The quiz button is to give a mini-quiz for interest students.

After all steps has done, then the researchers convert it from hyperlink PowerPoint to android application. It serves colorful, compatible sound effects and exciting animation. The researchers give standard animation to keep the user's concentration. The researchers hope students can understand well after playing the integrated quiz in each chapter.

\section{Development}

In this step the researchers design the storyboard before developing the media. The storyboard is made as the design of each scene in the press. After creating the flowchart and the storyboard, the researchers develop the first draft of the media.

The researchers validate the multimedia to experts before it is implemented to the students. There are comments and suggestions from experts. They are the English Education Department lecturer as the content expert and the lecturer of the Education Technology Department as the media expert. Both of them are lecturers of Unwaha University. Then, the researchers revise and develop the second draft of the media.

\section{Implementation}

After develop the media and validate it to the experts, finally, the English interactive media are implemented at grade VII of Mts Nizhamiyah Ploso. Then, the researchers ask for some feedback from the students and the teachers. The feedbacks are scores and suggestion. The data are collecting by using the second questionnaire.

\section{Evaluation}

In this step, the researchers evaluate and revise the media after implementation based on the feedback. Then, the researchers develop the final draft of the media.

\section{RESULTS AND DISCUSSION}

\section{Results of Need Analysis}


At this stage, the researchers conducted a need analysis on students. Data collection techniques at this stage used questionnaires. The purpose of the need analysis is to obtain data on students' needs in the English course. The data shown that students need different atmosphere in learning English. They want new teaching models which not only use textbook but another ways of teaching. The data from the results of the need analysis obtained are then used as a reference for designing the product storyboard.

\section{Results of Design}

From the result of the need analysis carried out at the beginning of the data obtained, it is used as a reference for making product storyboards. The storyboard is an initial description of the product to be developed. The detail of the storyboard is as follow:

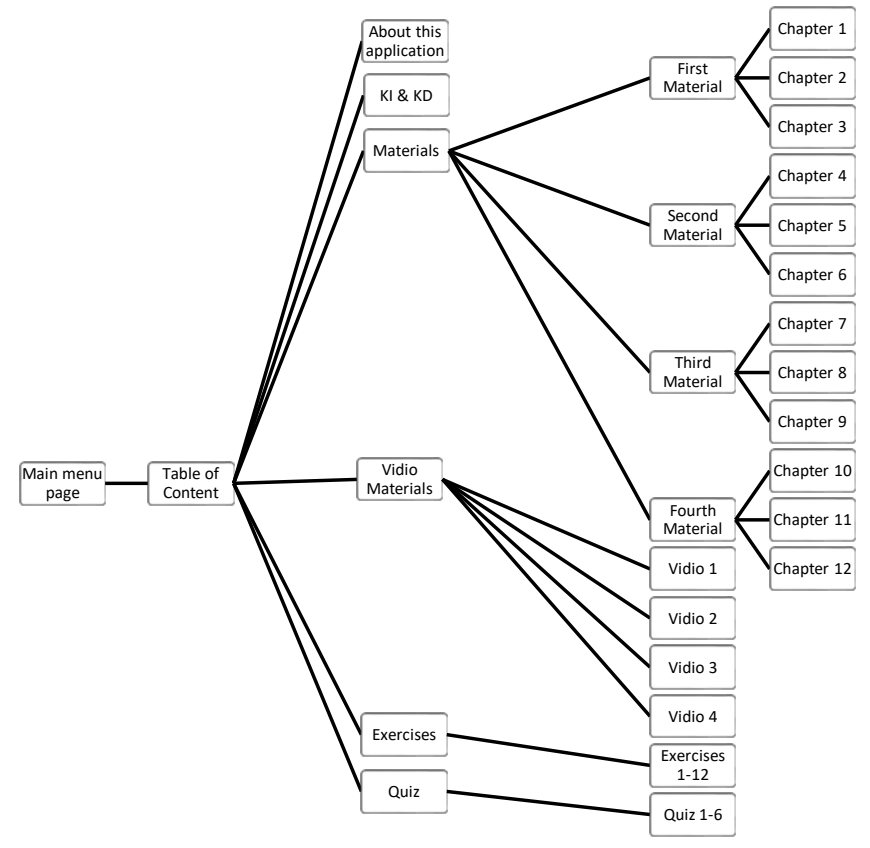

Figure 2. LEEF Storyboard

\section{Results of Development}

Result of Product Development

From the storyboard created by the researchers, the storyboard then began to develop. At the product development stage, the researchers use the Hyperlink PowerPoint. Then the researchers convert it into the android application using Ispring Suite and Web2apk Builder. The stages of product development and application of the design according to the storyboard are as follows:

1) Intro Page

The intro page is the initial page before the main menu on the LEEF app, and this page contains the title of the application and the description of the application. There is only one button on the intro page, namely the start button. This button function is as a button to start the application home page. The visual of the intro page can be seen in the following image: 


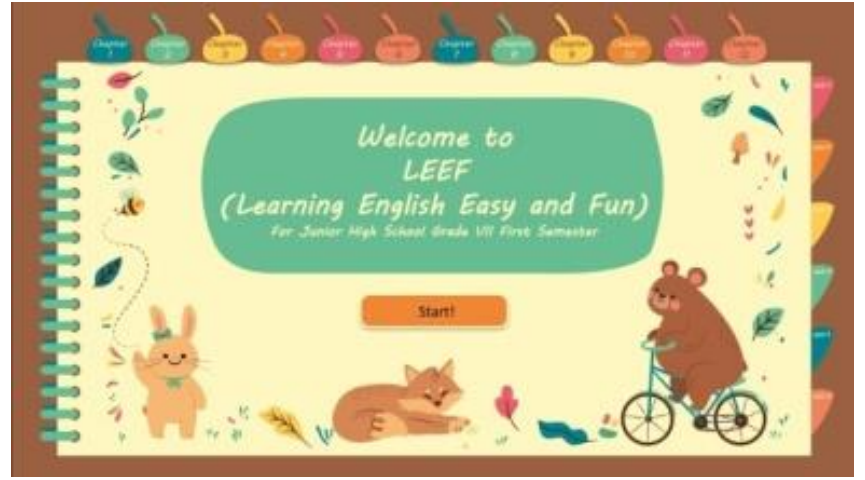

Figure 3. LEEF Intro Page

2) Homescreen Page

The home screen page is the main menu page of the LEEF app.On this page, there are six material menu buttons: About this Application, KI \& KD, Materials, Video Materials, also two evaluation menu button Exercises and Quiz. Each button is lead users to a different page when touched. The visual of the home-screen page are as follows:

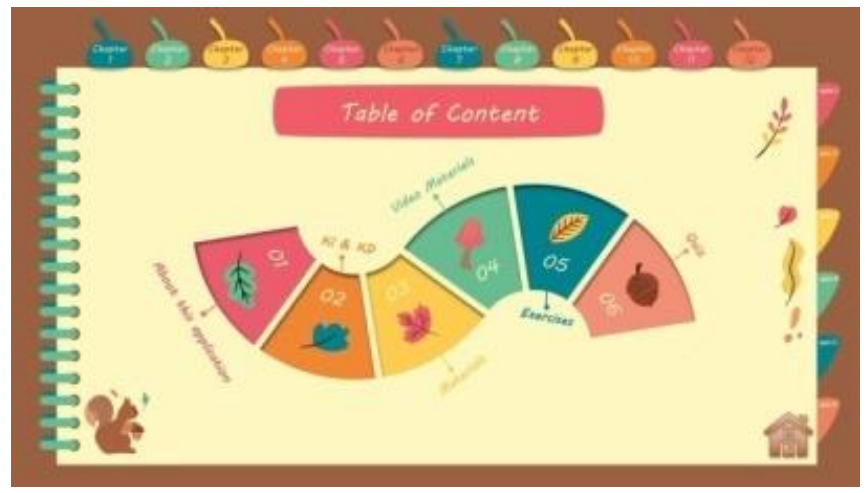

Figure 4. LEEF Home screen Page

3) About this application page

This layout explains about description of the LEEF application. Details of this layout are shown in the figure below:

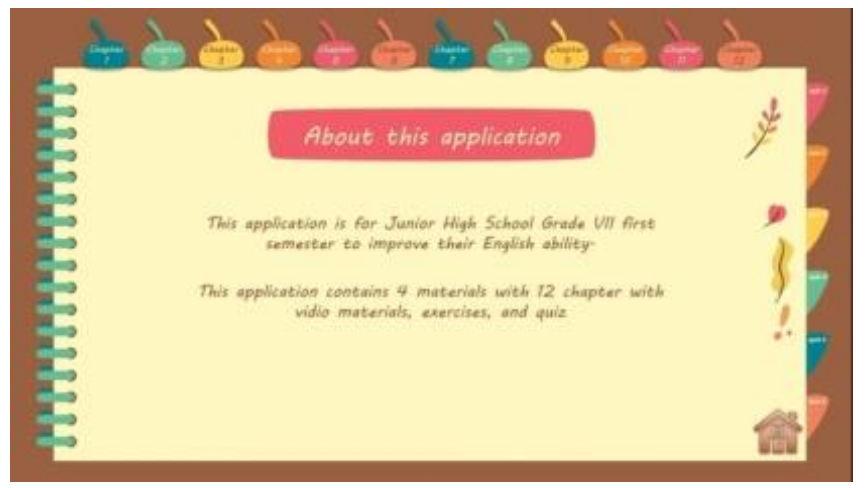

Figure 5. LEEF About this Application Page 
4) KI \& KD Page

This layout is containing $\mathrm{KI}$ and $\mathrm{KD}$ for each material, such as the figure below:

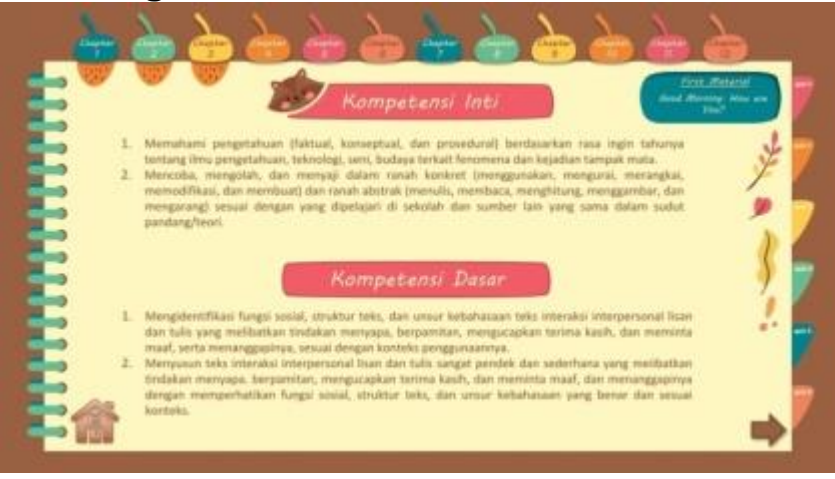

Figure 6. KI \& KD Page

\section{5) Materials Page}

This page contains four materials with twelve sub materials, andthe first materials are about Greeting, Gratitude and Apologizing Expression. The second materials are about Self Introduction, Introduction Family Members, Pronoun \& Spelling Alphabet. The third materials are about Time, Number, and Mathematic Operation. The fourth materials are about Singular and Plural, and Preposition of Place.There are 12 buttons in each slide which each button will lead the user to the sub materials. The layout is shown in the figure below :

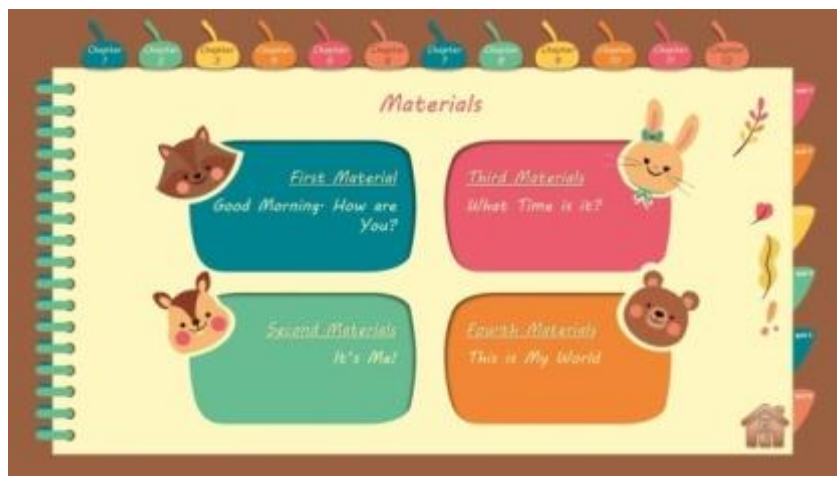

Figure 7. LEEF Materials Page

6) Video Materials Page

This page contains six videos: Greeting part I, Greeting part II, Greeting part III, Thanking and Apologizing part I, Thanking and Apologizing for part II, and Self Introduction. The layout is shown in the figure below : 


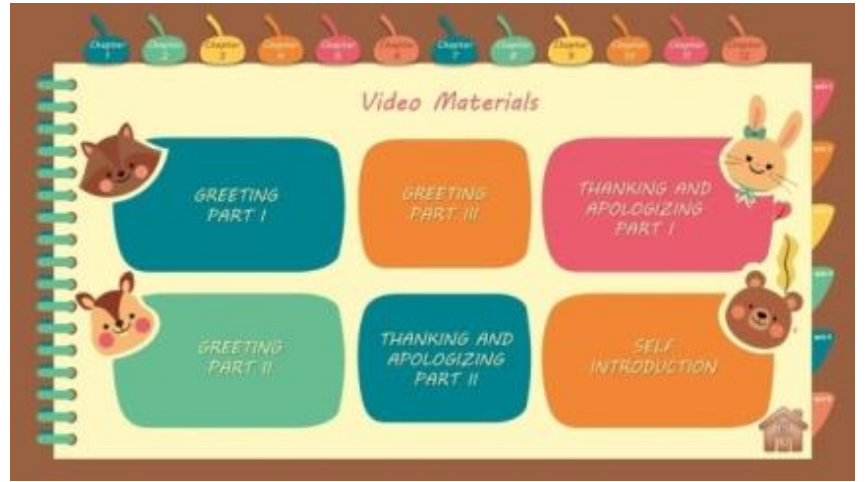

Figure 8. LEEF Video Materials Page

7) Exercises Page

This page is used to evaluate users after taking each course available in this product. There are 12 exercises, and student finishes it in their paper book, and after that, they can submit into the teacher, as the figure is shown below:

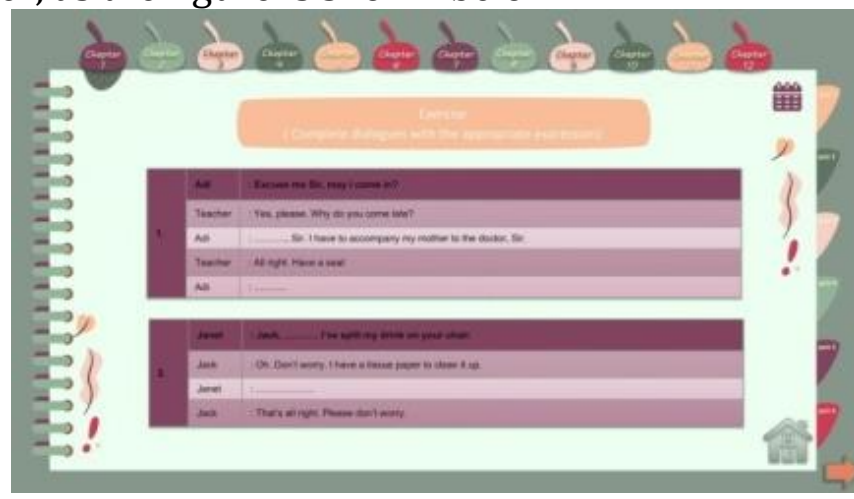

Figure 9. LEEF Exercises Page

8) Quiz Page

There is 27 questions multiple choice.Evaluation test based on the materials. as the figure is shown below:

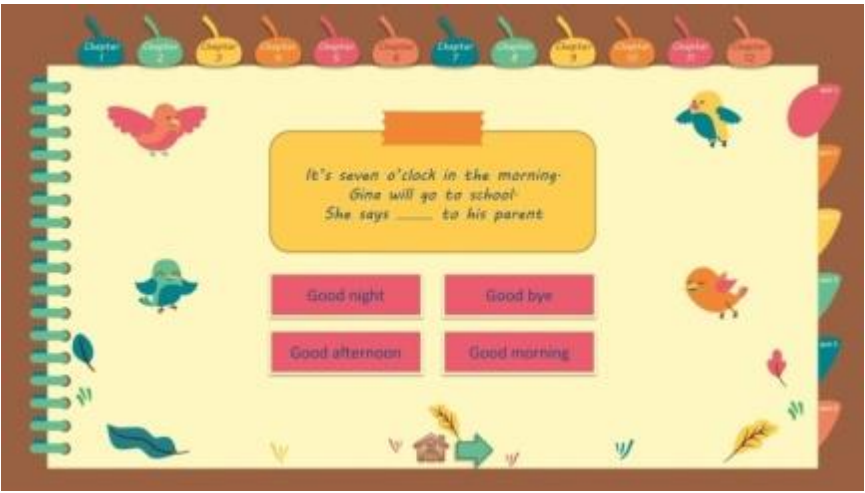

Figure 10. LEEF Quiz Page 


\section{Result of Expert Validation}

Two experts has validated the learning media, consisting of a media expert, Mrs Ulfa Wulan Agustina, M.Pd (Lecturer of ICT), and material expert, Mrs Luluk Choirun Nisak Nur, M. Pd (Lecturer English Education Department). The result from validation explains the materials and suggestions about video and picture that contained in the media then it will be fixed according to the advice from the experts. The data analysis technique used to calculate the score from the questionnaire used Likert's scale technique with five answer choices. Furthermore, the score obtained is converted into a value with a Likert's scale as shown in the table below:

Table 1. Likert's Scale

\begin{tabular}{cc}
\hline Meaning Score & Score \\
\hline Very Good & 5 \\
Good & 4 \\
Fair & 3 \\
Low & 2 \\
Very Low & 1 \\
\hline
\end{tabular}

The data collected then analyzed by finding the average score or mean as follows:

Description :

$$
x i=\frac{\sum x}{N}
$$

$x i=$ Average Score (Mean)

$\sum \mathrm{x} \quad=$ Total Score

$\mathrm{N} \quad=$ Number of question

\section{Result of Material Validation}

The material from learning media is tested for its feasibility by material experts,consisting of 1 examiner lecturer of the English Education Department. This analysis is used to determine the feasibility of the content or material on learning media developed based on four aspects which include, namely: 1) quality of material, 2) qualityof language, 3) Quality of evaluation task, 4) suitability of content. The measurement scale used is the Likert Scale,as explained earlier.After testing, improvements are made according to the advice of the experts. Resultassessment from the material are as follows :

Table 2. Assessment Result by Material Expert

\begin{tabular}{ccc}
\hline No & \multicolumn{1}{c}{ Aspek Penilaian } & Skor \\
\hline Kualitas materi & \\
1 & Tidak ada aspek indikator yang menyimpang & 5 \\
2 & Kejelasan isi materi (termasuk SK,KD, dan Indikator & 5 \\
3 & Uraian isi materi & 4
\end{tabular}


$4 \quad$ Kejelasan contoh yang disertakan

5 Kecakupan contoh yang disertakan

\section{Kualitas Bahasa}

6 Kejelasan bahasa yang digunakan 4

7 Kesesuaian bahasa dengan sasaran pengguna 3

\section{Kualitas soal latihan}

8 Kesesuaian soal latihan dengan kompetensi 4

9 Keseimbangan soal latihan dengan materi 4

10 Runtutan soal latihan yang disajikan

Kesesuaian sajian dengan tuntutan pembelajaran berpusat di peserta didik

11 Mendorong rasa keinginan peserta didik

12 Mendorong terjadinya interaksi peserta didik

13 Mendorong peserta didik membangun pengetahuanya sendiri

14 Mendorong peserta didik belajar secara mandiri

Based on the assessment result by a material expert, the total score get are 54; the total score then calculate using the formula explained earlier to know the eligibility of the learning media. The calculation is as follows :

$$
\text { Average Score }=\frac{\text { Total Score }}{\text { Number of Question }}=\frac{54}{14}=\mathbf{3 . 8 6}
$$

So, the result of the due diligence from material experts is 3.86, which is included in the category fair and worth using with revision. Based on the questionnaire responses from material experts, the following suggestions for improvements were obtained:

Table 3. Improvement Suggestion by Material Expert

\begin{tabular}{|c|c|c|}
\hline No & Validator & Saran Perbaikan \\
\hline 1 & $\begin{array}{l}\text { LulukChoirun } \\
\text { NisakNur, M. } \\
\text { Pd }\end{array}$ & $\begin{array}{l}\text { - } \quad \text { Penjelasan kalimat di dalam materi lebih dipermudah. } \\
\text { - } \quad \text { Disertakan gambar di dalam materi (time, preposition) } \\
\text { - } \quad \text { Contoh di materi disesuaikan }\end{array}$ \\
\hline & esimpulan & $\begin{array}{c}\begin{array}{l}\text { Tidak layak } \\
\text { digunakan }\end{array} \\
\begin{array}{l}\text { Layak digunakan } \\
\text { dengan revisi }\end{array} \\
\qquad \sqrt{ }\end{array}$ \\
\hline
\end{tabular}

\section{Result of Media Validation}

The Learning media is tested for its feasibility by media experts, consisting of 1 examiner lecturer of the English Education Department. This analysis is used to determine the feasibility of the content on learning media developed based on three aspects which 
include, namely: 1) common quality, 2) quality of language, 3) media presentation. The measurement scale used is the Likert Scale, as explained earlier. After testing, improvements are made according to the advice of the experts. Result assessment from the material are as follows :

Table 4. Result of Media Validation

\begin{tabular}{lcc}
\hline \multicolumn{1}{c}{ No } & Aspek Penilaian & Skor \\
\hline Kualitas Umum & \\
$1 \quad$ Kesesuaian media dengan Materi & 4 \\
$2 \quad$ Keteraturan dan Konsistensi Tampilan Tombol & 4 \\
Kualitas Bahasa & \\
$3 \quad$ Tata letak teks, gambar, dan animasi & 4 \\
4 & Kesesuaian pemilihan ukuran font & 4 \\
5 & Kesesuaian pemilihan background & 4 \\
Penyajian Media & \\
6 & Tampilan media yang menarik & 4 \\
7 & Sajian media yang menarik & 4 \\
8 & Terdapat judul/keterangan media & 4 \\
9 & Mampu Mendorong peserta didik belajar secara mandiri & 4 \\
\hline \multicolumn{2}{c}{ Total } & 36 \\
\hline
\end{tabular}

Table 4. Result of Product Revision

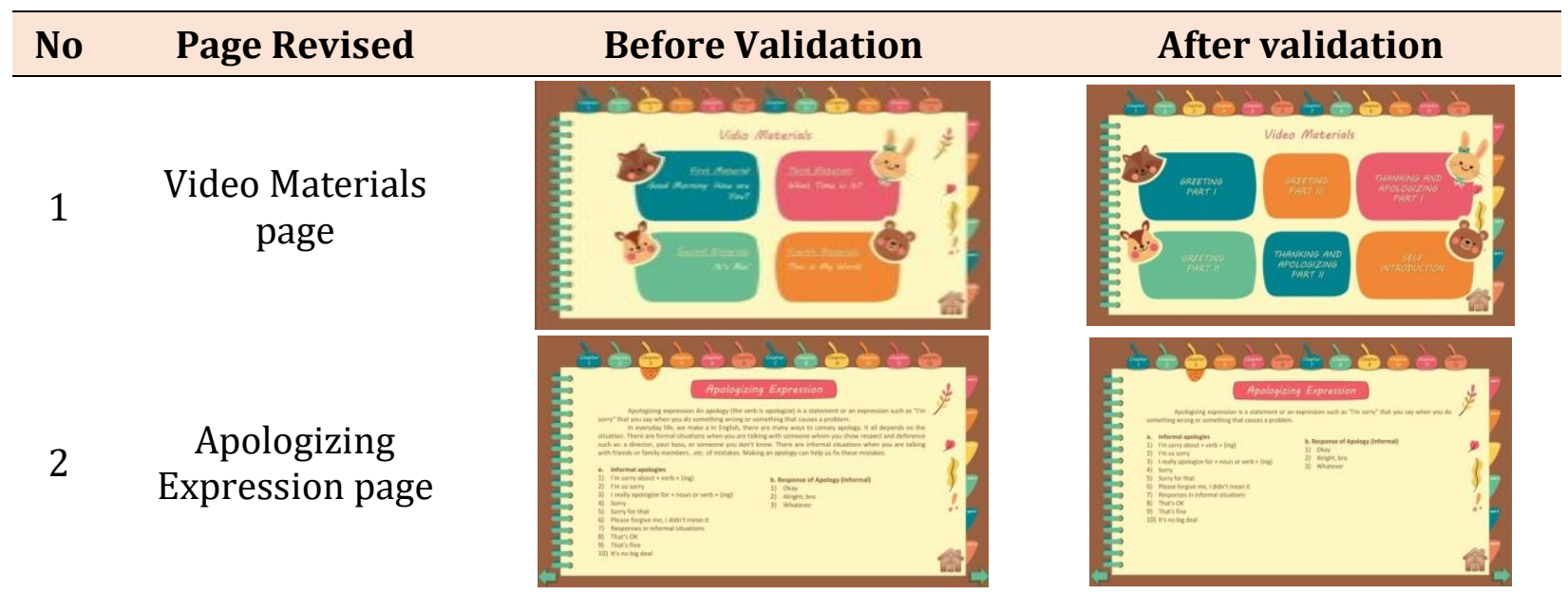


3

Preposition of Place page

4 Time material page

Gratitude Expression page
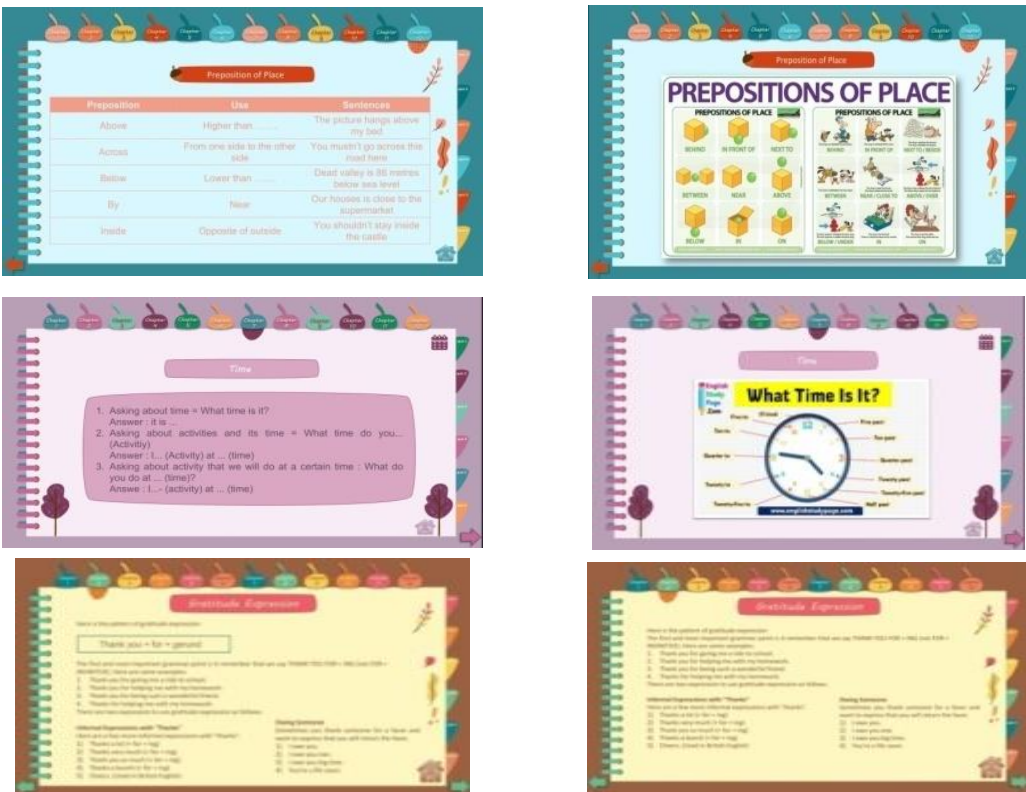

Based on the assessment result by media expert, the total score get are 36 . The total score then calculates using the formula explained earlier to know the eligibility of the learning media. The calculation is as follows :

$$
\text { Average Score }=\frac{\text { Total Score }}{\text { Number of Question }}=\frac{36}{9}=\mathbf{4 , 0 0}
$$

So, the result of the due diligence from material experts is 4,00 , which is included in the category fair and worth using with revision. Based on the questionnaire responses from material experts, the following suggestions for improvements were obtained:

Table 5. Improvement Suggestion by Media Expert

\begin{tabular}{|c|c|c|}
\hline No & Validator & Saran Perbaikan \\
\hline 1 & $\begin{array}{l}\text { Ulfa Wulan } \\
\text { Agustina, M.Pd }\end{array}$ & $\begin{array}{l}\text { Penambahan video pada media agar siswa lebih bisa } \\
\text { memahami materi. }\end{array}$ \\
\hline & Kesimpulan & $\begin{array}{ll}\begin{array}{ll}\text { Layak } \\
\text { dengan revisi }\end{array} & \begin{array}{l}\text { Layak digunakan } \\
\text { tanpa revisi }\end{array} \\
\sqrt{ } & \end{array}$ \\
\hline
\end{tabular}

\section{Result of Implementation}

At this stage, the learning media that has been developed then implemented in the Students grade VII first semester in MTs Nizhamiyah Ploso. The implementation of this learning media is carried out in the classroom to run the media individually. Before starting, the researchers shared a link to download the LEEF app, uploaded on the Google 
Drive site. Then students installed the app on each student's smartphone. Researchers demonstrate the use of learning media before students begin to try the learning media. After that, students are asked to start using learning media and try to do the evaluation provided. Students are then asked to fill out a respondent questionnaire to respond to the learning media.

Table 6. Implementation Collected Data

\begin{tabular}{|c|c|c|c|c|c|c|c|c|c|c|c|c|c|c|c|c|c|c|c|c|c|}
\hline \multirow{2}{*}{$\begin{array}{c}\text { Questi } \\
\text { on }\end{array}$} & \multicolumn{20}{|c|}{ Score Obtained by Students } & \multirow[t]{2}{*}{$\begin{array}{c}\text { Tota } \\
1\end{array}$} \\
\hline & 1 & 2 & 3 & 4 & 5 & 6 & 7 & 8 & 9 & 10 & 11 & 12 & 13 & 14 & 15 & 16 & 17 & 18 & 19 & 20 & \\
\hline 1 & 5 & 5 & 5 & 5 & 4 & 5 & 4 & 5 & 5 & 4 & 5 & 5 & 5 & 5 & 4 & 5 & 5 & 5 & 4 & 4 & 94 \\
\hline 2 & 5 & 4 & 4 & 4 & 4 & 4 & 5 & 4 & 4 & 5 & 4 & 4 & 4 & 4 & 5 & 5 & 5 & 4 & 5 & 4 & 87 \\
\hline 3 & 4 & 5 & 4 & 4 & 4 & 5 & 5 & 5 & 4 & 4 & 5 & 5 & 3 & 4 & 3 & 4 & 3 & 4 & 4 & 3 & 82 \\
\hline 4 & 5 & 5 & 4 & 5 & 4 & 4 & 4 & 5 & 3 & 4 & 4 & 4 & 4 & 4 & 3 & 4 & 5 & 5 & 4 & 4 & 84 \\
\hline 5 & 4 & 5 & 4 & 4 & 5 & 4 & 4 & 4 & 4 & 5 & 4 & 4 & 5 & 3 & 4 & 3 & 3 & 4 & 4 & 4 & 81 \\
\hline 6 & 5 & 5 & 4 & 4 & 5 & 4 & 4 & 5 & 4 & 5 & 5 & 4 & 3 & 4 & 5 & 4 & 4 & 5 & 4 & 4 & 87 \\
\hline 7 & 4 & 5 & 3 & 5 & 4 & 4 & 4 & 3 & 4 & 5 & 5 & 5 & 4 & 4 & 4 & 4 & 3 & 5 & 3 & 4 & 82 \\
\hline 8 & 4 & 5 & 4 & 4 & 5 & 4 & 4 & 4 & 5 & 4 & 4 & 4 & 4 & 4 & 4 & 5 & 5 & 4 & 4 & 5 & 86 \\
\hline 9 & 5 & 4 & 3 & 3 & 4 & 4 & 4 & 5 & 5 & 4 & 4 & 4 & 4 & 4 & 5 & 5 & 4 & 4 & 4 & 5 & 84 \\
\hline 10 & 4 & 4 & 4 & 5 & 5 & 4 & 5 & 4 & 3 & 5 & 5 & 5 & 5 & 3 & 4 & 4 & 3 & 4 & 4 & 3 & 83 \\
\hline 11 & 4 & 4 & 4 & 5 & 4 & 4 & 5 & 4 & 4 & 5 & 4 & 5 & 4 & 4 & 3 & 5 & 5 & 4 & 5 & 5 & 87 \\
\hline 12 & 5 & 5 & 4 & 4 & 5 & 5 & 4 & 5 & 4 & 4 & 4 & 4 & 5 & 5 & 4 & 3 & 4 & 4 & 5 & 4 & 87 \\
\hline 13 & 3 & 5 & 3 & 5 & 4 & 5 & 4 & 4 & 4 & 4 & 5 & 5 & 5 & 4 & 5 & 5 & 4 & 5 & 5 & 4 & 88 \\
\hline 14 & 4 & 5 & 4 & 4 & 4 & 4 & 4 & 5 & 4 & 4 & 4 & 4 & 4 & 4 & 4 & 3 & 5 & 5 & 3 & 4 & 82 \\
\hline 15 & 5 & 5 & 3 & 4 & 5 & 4 & 4 & 5 & 4 & 5 & 3 & 5 & 4 & 4 & 4 & 4 & 5 & 5 & 4 & 4 & 86 \\
\hline 16 & 4 & 4 & 4 & 5 & 4 & 4 & 4 & 5 & 3 & 4 & 4 & 5 & 4 & 3 & 4 & 5 & 3 & 5 & 4 & 5 & 83 \\
\hline 17 & 5 & 4 & 3 & 4 & 4 & 4 & 4 & 5 & 4 & 4 & 4 & 4 & 5 & 4 & 5 & 4 & 4 & 4 & 4 & 5 & 84 \\
\hline 18 & 4 & 5 & 4 & 4 & 5 & 4 & 4 & 5 & 4 & 4 & 4 & 5 & 4 & 4 & 5 & 5 & 5 & 4 & 4 & 5 & 88 \\
\hline & & & & & & & & & & Tot & & & & & & & & & & & 1.535 \\
\hline
\end{tabular}

According to the assessment result by respondents, the total score get are 1.535 . The total score then calculates using the formula explained earlier to know the eligibility of the learning media. The calculation is as follows :

$$
\text { Average Score }=\frac{\text { Total Score }}{\text { Number of participans }}=\frac{1535}{20}=\mathbf{7 6 , 8}
$$

The average score gets from the respondents are 76,8 . The data then again calculate with the following formula :

$$
\text { Average Score }=\frac{\text { Total Score }}{\text { Number of Question }}=\frac{76,8}{18}=\mathbf{4 , 2 6}
$$

So, the assessment result by respondents is 4.26 , which is included in the category good and worth using. 


\section{CONCLUSION}

This research was aimed at designing LEEF (Learning English Easy and Fun) learning media that can be used to support junior high students in learning English. The result of material validation got score 3.86 and the result of media validation was 4.00 which were in "good" category. It meant that this product (LEEF) was worthy to use. Furthermore the data from students responses to this media got score 4.26 which categorized in "good" category.

By having those conclusions, this research can give benefits for other people. For junior high students, they can use LEEF as learning media for supporting them in learning English while for the teachers can use it as a reference in giving their students material and exercise. Furthermore for other researchers, this learning media can be a reference to develop a new product in English learning.

\section{REFERENCES}

Abercrombie, D. (1949). Teaching pronunciation. ELT Journal, 3(5), 113-122. https://doi.org/10.1093/elt/III.5.113

Ahmad Rivai, Nana Sudjana. (2009). Media Pengajaran. Bandung: Sinar Baru Algesindo

Aka, K. A. (2019). Integration Borg \& Gall (1983) and Lee \& Owen (2004) models as an alternative model of design-based research of interactive multimedia in elementary school. Journal of Physics: Conference Series, 1318(1), 0-8. https://doi.org/10.1088/1742-6596/1318/1/012022

Anwar, C. R., Sos, S., \& Si, M. (2016). COMMUNICATION IN EDUCATION : AN ABANDONED RESEARCH ( Phenomenological Study of Communication of Education in Makassar ). 1, 350-356.

Baroroh, I. (2018). Improving S tudents 'Reading Comprehension by Activating Their Schema (An Action Research on VIII Grade of SMP Madinatul Ulum Tembelang Jombang ). 1(1), 14-26.

Dorf, R. C. (1969). Educational Technology. IEEE Transactions on Education, 12(1), 50-52. https://doi.org/10.1109/TE.1969.4320439

Taylor, L. (2004). Educational Theories and Instructional Design Models . Their Place in Simulation . Health. Retrieved from https://www.researchgate.net/publication/229039487_Educational_Theories_and_In structional_Design_Models_Their_Place_in_Simulation 